\title{
Protein Sources in Ruminant Nutrition
}

\author{
Monica I. Cutrignelli, Serena Calabrò, \\ Raffaella Tudisco, Federico Infascelli and Vincenzo Piccolo \\ Department of Animal Science and Food Control, \\ University of Naples Federico II, Naples, \\ Italy
}

\section{Introduction}

Since 2001 the European Commission banned the use of meat and bone meal and its byproducts in diets for livestock animals (EC directive 999/2001) in order to assure consumer safety on animal products. Consequently, soybean meal became the most utilised protein source in the intensive livestock systems.

Moreover, the proteins of this source are low degradable in the rumen and well proportioned to the non structural carbohydrates (NSC).

Soybean meal solvent extract (s.e.) is a by-product of oil industry, where soybean seeds are treated with organic solvents (e.g. hexane) and subsequently with high temperature. For this reason soybean meal has been banned in the organic livestock (EC directive 2092/1991; EC directive 834/2007).

Even if in Europe the high part of soybean is imported, soybean solvent extract represents the less expensive protein source for its high crude protein content (44-50\% as fed). However soybean meal costs and availability are strongly related with the price development of agricultural commodities on the world market (Jezierny et al., 2010). Factors which may influence world market prices include variations in population and economic growth, changes in consumer's product preferences, but world market prices are also dependent on weather conditions (Gill, 1997; Trostle, 2008).

Finally, another factor has to be evaluated that is the genetically modification (GM) of soybean. Indeed, public concerns are increasing in GM food consumption due to the fact, even if for several years no direct evidence that it may represent a possible danger for health has been reported, recently, a number of papers have been published with controversial results.

Thus, the search for alternative protein sources has led to an increasing interest in the use of grain legumes, as they supply the important source of plant protein.

The botanical family of grain legumes is known as Fabaceae, also referred to as Leguminosae. Grain legumes are cultivated primarily for their seeds which are harvested at maturity, and which are rich in protein and energy. The mature dry seeds of grain legumes are used either as animal feed ingredient or for human consumption (Singh et al., 2007). Beans, lentils and chickpeas are utilised exclusively for human nutrition, while the other grains are used in animal feeding too.

In Italy grain legumes cultivation is progressively increased due the presence of new cultivars more hardy and productive. These new cultivars were selected principally in 
France and are characterised by lower water requirements, higher production and higher resistance to the parasitic infestations and to the adverse environmental conditions.

Generally, legumes are characterised by their ability to use atmospheric nitrogen as a nutrient due to the symbiosis with nitrogen-fixing bacteria from the Rhizobium species (Sprent and Thomas, 1984; Zahran, 1999). Therefore, unlike other cultivated plants, legume crops need less nitrogen fertiliser for optimal growth, and the use of legumes in crop rotation systems reduces the need of nitrogen fertiliser in subsequent crops (López-Bellido et al., 2005). Nitrogen benefits in legume-cereal rotation systems have been attributed not only to the transfer of biologically fixed nitrogen (Díaz-Ambrona and Mínguez, 2001; Evans et al., 2001), but also to lower immobilisation of nitrate in the soil during the decomposition of legumes compared to cereal residues (Green and Blackmer, 1995), also termed as the nitrogen-sparing effect. Thus, nitrogen benefits may result from a combination of legume nitrogen sparing effects and the bacterial nitrogen fixation (Chalk et al., 1993; Herridge et al., 1995). In addition, crop rotation and intercropping with legumes may provide successful strategies for weed suppression (Liebman and Dyck, 1993; Bulson et al., 1997). Weed growth and development may be disrupted due to varying cultivation conditions prevailing for the different crops used (e.g. fertiliser requirements, planting or maturation dates), thereby preventing domination of only a few weed species (Froud-Williams, 1988; Liebman and Janke, 1990). Due to these crop effects, cultivation of grain legumes is an important part of crop rotation, particularly in organic farming (Badgley et al., 2007).

In animal nutrition, grain legumes are mainly used as protein supplements, but also as a valuable energy source, due to their partly high contents of starch (faba bean, peas) and lipids (lupins) (Gatel, 1994; Bach Knudsen, 1997; Salgado et al., 2002a).

However, the use of grain legumes in animal nutrition has been hampered due to partially high concentrations of secondary plant metabolites, also referred as antinutritional factors (ANFs), including condensed tannins, protease inhibitors, alkaloids, lectins, pyrimidine glycosides and saponins. Possible negative effects of these secondary plant metabolites include, for example, feed refusals (tannins, alkaloids), reduced nutrient digestibility (tannins, protease inhibitors, lectins) or even toxic effects (alkaloids) (Rubio and Brenes, 1995; Lallès and Jansman, 1998; Huisman and Tolman, 2001).

The objectives of the following chapters are the comparison of chemical composition as well as the nutritive value of soybean, soybean meal solvent extract and several legume grain (e.g.: peas, lupine, faba bean). In addition, in order to evaluate the opportunity of soybean replacement with grain, the results of in vitro studies are described and the influence of protein sources on meat quality are discussed.

\section{Nutritional characteristics of soybean meal solvent extract and legume grains}

The chemical composition of some grain legumes in comparison to soybean and soybean meals s.e are pictured in Table 1.

Soybeans (Soja hispida) are characterized by high protein $(380 \mathrm{~g} / \mathrm{kg}$ dry matter) and lipid (200 g/kg dry matter) concentrations, which provide high energy density (1.1-1.2 UFL/kg dry matter). In ruminant feeding, soybean integral seeds could represent the only source of protein supplementation for cattle fattening. However, in dairy cows it is preferable not to exceed the dry matter administration of soybean seeds as it may modify fatty acid profile of milk fat and worse butter consistency and conservation. 
Soybean meal s.e. proteins, due to the heat treatment, are medium to low degradable in the rumen (Chaubility et al., 1991; Infascelli et al., 1995). In addition, soybean meal shows an elevated ratio of protein/non structural carbohydrates.

Legume grains are characterised by high energy density allowed to the high protein, starch and/or fat concentrations, as more than sufficient is their calcium concentration.

The proteins of legume grain are highly degradable in the rumen and digestible in the intestine. Notwithstanding, large part of legume grain shows anti-nutritional factors (i.e. lecithin, trypsin inhibitors, tannins, saponin, phytase), that are inactivated by the enzymes produced by the bacteria present in the rumen. Within the grain legumes, lupins have higher amounts of crude protein (324-381 g/ kg dry matter), compared to faba beans (301 $\mathrm{g} / \mathrm{kg}$ dry matter) and peas (246 g/kg dry matter) (Degussa, 2006). Jezierny et al. (2007) reported similar contents of crude protein in different batches of lupins, faba beans and peas averaging 387, 308 and $249 \mathrm{~g} / \mathrm{kg}$ dry matter, respectively. In comparison to soybean meal, faba beans and peas contain between 45 to $55 \%$ and lupins (L. albus) even up to $70 \%$ of its crude protein content (Degussa, 2006).

The ether extract content in peas and faba beans is generally rather low compared to lupins; crude fat contents of faba beans and peas range from 15 to $20 \mathrm{~g} / \mathrm{kg}$ dry matter, thus being in a similar range as values for soybean meal (15-28 g/ kg dry matter) (DLG, 1999; Jezierny et al., 2007). In lupins, the crude fat content varies between cultivars, with values of about 57 $\mathrm{g} / \mathrm{kg}$ dry matter (L. luteus, L. angustifolius) to $88 \mathrm{~g} / \mathrm{kg}$ dry matter (L. albus) (DLG, 1999).

The carbohydrate fraction includes the low molecular-weight sugars, starch and various non-starch-polysaccharides (NSP) (Bach Knudsen, 1997). The NSP and lignin are the principal components of cell walls and are commonly referred to as dietary fibre (Theander et al., 1989; Canibe and Bach Knudsen, 2002). Generally, faba beans and peas are rich in starch (422-451 and 478-534 g/kg dry matter, respectively) (DLG, 1999; Jezierny, 2009), whereas lupins have comparatively low levels of starch (42-101 g/ kg dry matter) (DLG, 1999; Jezierny, 2010). However, it needs to be emphasized that the determination of starch in grain legumes may be confounded by the analytical method used (Hall et al., 2000).

Faba beans and peas contain rather low amounts of fibre fractions in comparison to lupins (Bach Knudsen, 1997; Jezierny, 2009), and, with regard to lignin content, faba beans and $L$. angustifolius have similar amounts of lignin (1 to 7 and 6 to $9 \mathrm{~g} / \mathrm{kg}$ dry matter, respectively), whereas the lignin content in peas is of minor importance $(0.4-3 \mathrm{~g} / \mathrm{kg}$ dry matter) (Salgado et al., 2002a; Jezierny, 2010).

The NSP fraction of faba beans consists mainly of cellulose (89-115 g/kg dry matter), with lower levels of hemicellulose (21-57 g/kg dry matter) (Salgado et al., 2002a,b; Jezierny, 2009).

Hemicellulose contents in peas range from 23 to $95 \mathrm{~g} / \mathrm{kg}$ dry matter and cellulose contents range from 52 to $77 \mathrm{~g} / \mathrm{kg}$ dry matter (Salgado et al., 2002a,b; Jezierny, 2009).

Lupins contain high levels of NSP, with contents of cellulose generally being higher than hemicellulose (131 to 199 vs. 40 to $66 \mathrm{~g} / \mathrm{kg}$ dry matter) (Bach Knudsen, 1997; Salgado et al., 2002a,b; Jezierny, 2009), and they also have considerable amounts of oligosaccharides (Bach Knudsen, 1997; Salgado et al., 2002a).

Comparing the different batches in each species, lupin show lower variability than faba bean and peas, probably because the genetic selection in this species was addressed principally on the reduction of secondary plant metabolites (Colombini, 2004) than to the improving of chemical characteristics. 
The protein of faba beans and peas contains similar or even higher proportions of lysine (70 and $80 \mathrm{~g} / \mathrm{kg}$ crude protein, respectively), when compared to protein from soybean meal s.e. (69 $\mathrm{g} / \mathrm{kg}$ crude protein) or lupins (51 to $54 \mathrm{~g} / \mathrm{kg}$ crude protein) (Degussa, 2006).

Comparing the different batches in each species, lupin show lower variability than faba bean and peas, probably because the genetic selection in this species was addressed principally on the reduction of secondary plant metabolites (Colombini, 2004) than to the improving of chemical characteristics.

Comparing the different batches in each species, lupin show lower variability than faba bean and peas, probably because the genetic selection in this species was addressed principally on the reduction of secondary plant metabolites (Colombini, 2004) than to the improving of chemical characteristics.

\begin{tabular}{|l|c|c|c|c|c|}
\hline \multicolumn{1}{|c|}{ Protein sources } & DM & CP & EE & Ash & NDF \\
\hline Soybean & 93.30 & 33.2 & 25.0 & 5.57 & 14.5 \\
\hline Soybean meal s.e. & 89.80 & 41.3 & 1.36 & 6.00 & 22.2 \\
\hline Lupin Lublanc & 93.26 & 36.92 & 6.78 & 4.33 & 4.33 \\
\hline Lupin Lutteur & 94.31 & 35.30 & 5.73 & 4.19 & 4.19 \\
\hline Lupin Multitalia & 93.97 & 36.67 & 9.54 & 3.92 & 3.92 \\
\hline Faba bean Irena & 89.22 & 25.62 & 1.05 & 3.99 & 20.94 \\
\hline Faba bean Lady & 88.48 & 25.17 & 1.02 & 4.21 & 25.82 \\
\hline Faba bean Scuro di Torre Lama & 90.55 & 26.91 & 0.90 & 4.32 & 21.75 \\
\hline Faba bean Chiaro di Torre Lama & 90.80 & 24.69 & 1.01 & 4.19 & 21.23 \\
\hline Faba bean ProtHABAT69 & 90.60 & 28.69 & 1.10 & 4.51 & 18.21 \\
\hline Faba bean Sicania & 90.29 & 26.52 & 0.95 & 3.89 & 21.43 \\
\hline Peas Alembo & 88.49 & 31.27 & 0.73 & 3.94 & 21.60 \\
\hline Peas Alliance & 89.20 & 28.47 & 0.56 & 3.82 & 20.40 \\
\hline Peas Attika & 89.68 & 25.04 & 0.81 & 4.01 & 18.09 \\
\hline Peas Corallo & 88.80 & 28.50 & 0.80 & 3.69 & 21.82 \\
\hline Peas Iceberg & 90.08 & 27.30 & 0.78 & 4.12 & 22.75 \\
\hline Peas Ideal & 89.94 & 28.28 & 0.88 & 4.17 & 18.37 \\
\hline Peas Spirale & 93.00 & 28.74 & 0.55 & 4.30 & 19.05 \\
\hline
\end{tabular}

Table 1. Mean values of chemical composition (\%dry matter) of different protein sources (Calabrò et al., 2001; Calabrò et al., 2009; Calabrò et al., 2010).

Comparing the different batches in each species, lupin show lower variability than faba bean and peas, probably because the genetic selection in this species was addressed principally on the reduction of secondary plant metabolites (Colombini, 2004) than to the improving of chemical characteristics.

The protein of faba beans and peas contains similar or even higher proportions of lysine (70 and $80 \mathrm{~g} / \mathrm{kg}$ crude protein, respectively), when compared to protein from soybean meal (69 $\mathrm{g} / \mathrm{kg}$ crude protein) or lupins (51 to $54 \mathrm{~g} / \mathrm{kg}$ crude protein) (Degussa, 2006).

The proportion of threonine in grain legume protein ( 38 to $42 \mathrm{~g} / \mathrm{kg}$ crude protein) is similar to that in soybean meal (45 g/ kg soybean meal) (Degussa, 2006), however, there is a severe deficiency in the sulphur containing AA methionine + cystine, while tryptophan is marginally deficient to fulfill nutrient requirements for pigs (20 to $50 \mathrm{~kg}$ body weight) (NRC, 1998; Degussa, 2006). In fact, apart from L. albus, the seeds of faba beans, peas and lupins 
contain less than $50 \%$ of these AA in comparison to soybean meal (Table 2), thus constraining the use of grain legumes as sole protein source in pig diets.

\begin{tabular}{|c|c|c|c|c|c|c|}
\hline & Vicia faba & Pisum sativum & Lupinus albus & $\begin{array}{c}\text { Lupinus } \\
\text { angustifolius }\end{array}$ & $\begin{array}{l}\text { Lupinus } \\
\text { luteus }\end{array}$ & SBM \\
\hline $\mathrm{CP}$ & 301 & 246 & 381 & 324 & 361 & 541 \\
\hline \multicolumn{7}{|c|}{ Indispensable AA } \\
\hline Arginine & 26.4 & 21.0 & \begin{tabular}{|l|}
39.3 \\
\end{tabular} & 33.5 & 38.0 & 39.7 \\
\hline Histidine & 7.8 & 6.1 & 9.3 & 8.8 & 9.7 & 14.4 \\
\hline Isoleucine & 11.8 & 10 & 15.3 & 12.7 & 14.2 & 24.3 \\
\hline Leucine & 21.4 & 17.4 & 27.5 & 21.5 & 24.1 & 40.9 \\
\hline Lysine & 18.4 & 17.3 & 18.2 & 15 & 16.3 & 33.1 \\
\hline Methionine & 2.2 & 2.2 & 2.5 & 2.0 & 2.0 & 7.3 \\
\hline $\begin{array}{l}\text { Phenyl- } \\
\text { alanine }\end{array}$ & 12.6 & 11.7 & 14.9 & 12.5 & 13.6 & 27.2 \\
\hline Threonine & 10.5 & 9.1 & 13.3 & 10.9 & 11.9 & 21.3 \\
\hline Tryptophan & 2.6 & 2.2 & 3.0 & 2.6 & 3.0 & 7.4 \\
\hline Valine & 13.3 & 11.4 & 14.5 & 12.5 & 13.6 & 25.5 \\
\hline \multicolumn{7}{|c|}{ Dispensable AA } \\
\hline Alanine & 11.9 & 10.5 & \begin{tabular}{|l|}
12.5 \\
\end{tabular} & 10.9 & 11.8 & 23.3 \\
\hline $\begin{array}{l}\text { Aspartic } \\
\text { acid }\end{array}$ & 31.6 & 28.2 & 38.5 & 31.5 & 35.1 & 62.0 \\
\hline Cystine & 3.5 & 3.5 & 6.7 & 4.3 & 4.8 & 8.0 \\
\hline $\begin{array}{l}\text { Glutamic } \\
\text { acid }\end{array}$ & 46.9 & 40.0 & 79.3 & 65.6 & 72.5 & 97.6 \\
\hline Glycine & 12.2 & 10.6 & 15.0 & 13.4 & 14.3 & 23.0 \\
\hline Proline & 11.8 & 10.2 & 15.3 & 13.5 & 14.3 & 27.5 \\
\hline Serine & 14.1 & 11.5 & 19.0 & 15.3 & 17.0 & 27.3 \\
\hline
\end{tabular}

Table 2. Amino acid contents of grain legumes compared to soybean meal (g/ $\mathrm{kg}$ dry matter) (Jezierny et al., 2010) $\mathrm{SBM}=$ soybean meal; $\mathrm{CP}=$ crude protein; $\mathrm{AA}=$ amino acids.

As concerns the fatty acid profile, the rather high proportion of essential unsaturated fatty acids of some grain legumes, e.g. some Vicia species (Akpinar et al., 2001) or L. albus (Erbas, et al., 2005) may be attractive both from the human and animal nutrition perspective (Bézard et al., 1994), while adverse effects of unsaturated fatty acids on meat quality should be taken into account (Wood et al., 2003). For example, in faba beans a ratio of saturated to unsaturated fatty acids of 40-60 has been reported (Akpinar et al., 2001), whereas in L. albus, a ratio of saturated, monounsaturated and polyunsaturated fatty acids of 13.5 to 55.4 to 31.1 has been established (Erbas, et al., 2005).

As concerns the mineral composition of soybean and grain legumes, only few data are reported in literature.

The calcium concentration ranges between $1.0 \mathrm{~g} / \mathrm{kg}$ (faba beans) and $1.9 \mathrm{~g} / \mathrm{kg}$ ( $L$. angustifolius). Phosphorus concentration varies between $4.2 \mathrm{~g} / \mathrm{kg}$ (L. angustifolius) and 7.6 $\mathrm{g} / \mathrm{kg}$ (L. luteus). No extreme differences in trace mineral concentrations occurred except for the manganese concentration of L. albus, which containes approximately 10 times more manganese than the other legume grains (Brand et al., 2004). 
Concerning the trace elements, Cabrera et al (2003) reported that in legumes their levels ranged from 1.5-5.0 $\mu \mathrm{g} \mathrm{Cu} / \mathrm{g}$, 0.05-0.60 $\mu \mathrm{g} \mathrm{Cr} / \mathrm{g}$, 18.8-82.4 $\mu \mathrm{g} \mathrm{Fe} / \mathrm{g}$, 32.6-70.2 $\mu \mathrm{g} \mathrm{Zn/g,} \mathrm{2.7-}$ $45.8 \mu \mathrm{g} \mathrm{Al} / \mathrm{g}, 0.02-0.35 \mu \mathrm{g} \mathrm{Ni} / \mathrm{g}, 0.32-0.70 \mu \mathrm{g} \mathrm{Pb} / \mathrm{g}$ and not detectable $-0.018 \mu \mathrm{g} \mathrm{Cd} / \mathrm{g}$. In nuts, the levels ranged from 4.0-25.6 $\mu \mathrm{g} \mathrm{Cu} / \mathrm{g}, 0.25-1.05 \mu \mathrm{g} \mathrm{Cr} / \mathrm{g}$, 7.3-75.6 $\mu \mathrm{g} \mathrm{Fe} / \mathrm{g}$, 25.6$69.0 \mu \mathrm{g} \mathrm{Zn/g}, 1.2-20.1 \mu \mathrm{g} \mathrm{Al} / \mathrm{g}, 0.10-0.64 \mu \mathrm{g} \mathrm{Ni} / \mathrm{g}, 0.14-0.39 \mu \mathrm{g} \mathrm{Pb} / \mathrm{g}$, and not detectable$0.018 \mu \mathrm{g} \mathrm{Cd} / \mathrm{g}$. The authors found a direct statistical correlation between $\mathrm{Cu}-\mathrm{Cr}, \mathrm{Zn}-\mathrm{Al}$ and $\mathrm{Cr}-\mathrm{Ni}(\mathrm{P}<0.05)$, and $\mathrm{Al}-\mathrm{Pb}(\mathrm{P}<0.001)$.

Sankara Rao and Deosthale (2006) comparing for their total ash, calcium, phosphorus, iron, magnesium, zinc, manganese, copper, and chromium contents five grain legumes (indian legumes, chick pea, pigeon pea, green gram, and black gram), found significant varietal differences only for chromium content in black gram. The cotyledons of these legumes were significantly lower in calcium content as compared to the whole grains. The authors concluded that for human nutrition, differences in mineral composition of whole grain and cotyledons were marginal except for calcium. These legumes as whole grain and cotyledons, appeared to be significant contributors to the daily requirements of magnesium, manganese, and copper in the diet.

As concerns the mineral composition of soybean and grain legumes, only few data are reported in literature.

The calcium concentration ranges between $1.0 \mathrm{~g} / \mathrm{kg}$ (faba beans) and $1.9 \mathrm{~g} / \mathrm{kg}$ ( $L$. angustifolius). Phosphorus concentration varies between $4.2 \mathrm{~g} / \mathrm{kg}$ (L. angustifolius) and 7.6 $\mathrm{g} / \mathrm{kg}$ (L. luteus). No extreme differences in trace mineral concentrations occurred except for the manganese concentration of L. albus, which containes approximately 10 times more manganese than the other legume grains (Brand et al., 2004).

Concerning the trace elements, Cabrera et al (2003) reported that in legumes their levels ranged from 1.5-5.0 $\mu \mathrm{g} \mathrm{Cu} / \mathrm{g}$, 0.05-0.60 $\mu \mathrm{g} \mathrm{Cr} / \mathrm{g}$, 18.8-82.4 $\mu \mathrm{g} \mathrm{Fe} / \mathrm{g}$, 32.6-70.2 $\mu \mathrm{g} \mathrm{Zn/g,} \mathrm{2.7-}$ $45.8 \mu \mathrm{g} \mathrm{Al} / \mathrm{g}, 0.02-0.35 \mu \mathrm{g} \mathrm{Ni} / \mathrm{g}, 0.32-0.70 \mu \mathrm{g} \mathrm{Pb} / \mathrm{g}$ and not detectable $-0.018 \mu \mathrm{g} \mathrm{Cd} / \mathrm{g}$. In nuts, the levels ranged from 4.0-25.6 $\mu \mathrm{g} \mathrm{Cu} / \mathrm{g}, 0.25-1.05 \mu \mathrm{g} \mathrm{Cr} / \mathrm{g}, 7.3-75.6 \mu \mathrm{g} \mathrm{Fe} / \mathrm{g}$, 25.6$69.0 \mu \mathrm{g} \mathrm{Zn} / \mathrm{g}, 1.2-20.1 \mu \mathrm{g} \mathrm{Al} / \mathrm{g}, 0.10-0.64 \mu \mathrm{g} \mathrm{Ni} / \mathrm{g}, 0.14-0.39 \mu \mathrm{g} \mathrm{Pb} / \mathrm{g}$, and not detectable$0.018 \mu \mathrm{g} \mathrm{Cd} / \mathrm{g}$. The authors found a direct statistical correlation between $\mathrm{Cu}-\mathrm{Cr}, \mathrm{Zn}-\mathrm{Al}$ and $\mathrm{Cr}-\mathrm{Ni}(\mathrm{P}<0.05)$, and $\mathrm{Al}-\mathrm{Pb}(\mathrm{P}<0.001)$.

Sankara Rao and Deosthale (2006) comparing for their total ash, calcium, phosphorus, iron, magnesium, zinc, manganese, copper, and chromium contents five grain legumes (indian legumes, chick pea, pigeon pea, green gram, and black gram), found significant varietal differences only for chromium content in black gram. The cotyledons of these legumes were significantly lower in calcium content as compared to the whole grains. The authors concluded that for human nutrition, differences in mineral composition of whole grain and cotyledons were marginal except for calcium. These legumes as whole grain and cotyledons, appeared to be significant contributors to the daily requirements of magnesium, manganese, and copper in the diet.

\section{In vitro evaluation of soybean and legume grains}

The nutritive value of a feed is assessed by its chemical composition, digestibility and level of voluntary intake. Feed evaluation methods are use to express nutritive value of feed. It is basically description of feeds interns that allow for a prediction of the performance of animals offered the feeds (Medsen et al., 1997).

Several methods are used in feed evaluation such as chemical analysis, rumen degradability measurement using the nylon bag technique, digestibility measurement and feed intake 
prediction. However, the tables supply mean values, which cannot be used for individual lots, and all the in vivo techniques are very expensive and time consuming while accuracy may be low.

The in vitro gas production technique (IVGPT, Theodorou et al., 1994) has proved to be a potentially useful technique for ruminant feed evaluation (Herrero et al., 1996; Getachew et al., 2004), as it is capable of measuring rate and extent of nutrient degradation (Groot et al., 1996; Cone et al., 1996).

To evaluate a feedstuff by IVGPT, it is incubated at $39^{\circ} \mathrm{C}$ and under anaerobiosis condition with buffered rumen fluid and gas produced is measured as an indirect indicator of fermentation kinetics. During the incubation the feedstuff is first degraded and the degraded fraction may either be fermented to produce gas ( $\mathrm{CO}^{2}$ and methane) and fermentation acids, or incorporated into microbial biomass.

The IVGPT is considered the most complete in vitro technique, because it allows to estimate the fermentation kinetics and contemporary gives information on the fermentation products (degradability of dry matter, volatile fatty acids).

The IVGPT has been used by our research group for many years in order to investigate feed fermentation kinetics.

In particular, in this chapter we report some results obtained incubating different protein sources (i.e. soybean and legumes grains) in order to compare their fermentation kinetics (Calabrò et al., 2001a), to assess the effect of some technological treatments (i.e. crushing and flaking) on the carbohydrates fermentation kinetics (Calabrò et al., 2001b) and to test different legumes grain cultivars (Calabrò et al., 2009).

Calabrò et al. (2001a), in order to study the in vitro fermentation characteristics and kinetics proposed the following protocol: the samples (about $1.00 \mathrm{~g}$ ), ground to pass a $1 \mathrm{~mm}$ screen, were incubated in triplicate at $39^{\circ} \mathrm{C}$ in $120 \mathrm{ml}$ serum bottles under anaerobic conditions. Rumen liquor for the inoculum was collected from four buffaloes fed a standard diet, and immediately transported to the laboratory where it was homogenised and filtered.

The gas measurements was made at 2-24 time intervals using a manual a pressure transducer (figure 1).

The cumulative gas produced at each time was fitted to the Groot et al. (1996) model which estimates the asymptotic value $(\mathrm{A}, \mathrm{ml} / \mathrm{g})$, the time after incubation at which $\mathrm{A} / 2$ is formed $(B, h)$, the time to reach the maximum rate $(\operatorname{tmax}, h)$ and the maximum rate $(\mathrm{Rmax}, \mathrm{ml} / \mathrm{h})$.

At the end of incubation, the degraded organic matter (dOM, \%) was calculated as a difference between incubated and residual OM (filtering the bottle content through preweighed glass crucibles and burning at $550^{\circ} \mathrm{C}$ for 3 hours), and $\mathrm{pH}$ and volatile fatty acid concentration (VFA, $\mathrm{mM} / \mathrm{g}$ ) were determined, using a $\mathrm{pH}$-meter and a gas chromatography, respectively.

Several concentrate ingredients such as cereals and grain legumes, used in ruminant diets in order to increase production levels, were evaluated. In particular barley, maize, hard wheat, soft wheat, oats, faba bean and pea were used as test substrates.

Carbohydrates fractionation was carried out according to Cornell Net Carbohydrate and Protein System (CNCPS, Sniffen et al., 1992).

The Cornell Net Carbohydrate and Protein System was developed to predict requirements, feed utilization, animal performance and nutrient excretion for dairy and beef cattle and sheep, using accumulated knowledge about feed composition, digestion, and metabolism in supplying nutrients to meet requirements. 


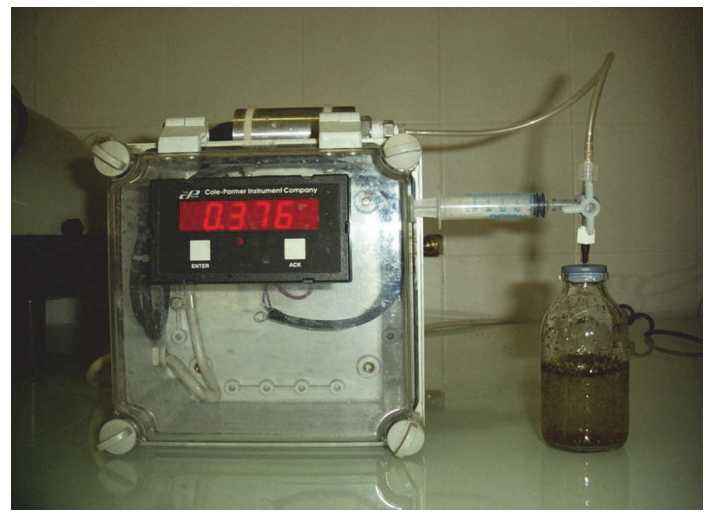

Fig. 1. Pressure transducer.

The CNCPS partitions crude protein into fractions A, B, and C, depending on their rate and extent of degradability in the rumen (NRC, 2001). Fraction A represents the non-protein $\mathrm{N}$ (NPN) (ammonia, peptides, amino acids) and is considered to be completely soluble; fraction B, subdivided into B1, B2, and B3, consists of true protein with progressively declining ruminal degradability. Fraction $C$ is unavailable true protein. Broadly, these crude protein fractions are categorized into rumen degradable protein (RDP) and rumen undegradable protein (RUP). The rumen degradable protein meets protein requirements for ruminal microbial growth and protein synthesis.

Once reaching the rumen, feed and protein degradation is a function of microbial activity. Rumen microbial activity, growth and protein synthesis is primarily limited by the rate and extent of carbohydrate fermentation in the rumen. Consequently, dietary fiber fractions in the forage determine the animal response to feed.

Microbial protein and rumen undegradable protein reaching the small intestine are absorbed to meet the ruminant's protein requirement. When rumen degradable protein exceeds the capacity of the rumen microbes to assimilate it, ammonia builds up in the rumen. This is followed by absorption of ammonia into the blood, conversion into urea by the liver, and excretion in the urine. The conversion of ammonia to urea costs the dairy cow energy that could otherwise be used for milk production. This loss of dietary crude protein and energy reduces the utilization efficiency of rumen degradable protein and therefore, reduced ruminant production (NRC, 2001). It also causes a negative energy balance that leads to a reduced fertility.

In the study of Calabrò et al. (2001a), the CNCPS carbohydrate fractions (table 3) was consistent with the values reported by Sniffen et al. (1992).

Oats (table 4) had the lowest potential gas production (A: $251 \mathrm{ml} / \mathrm{g}, \mathrm{P}<0.0$ ) and a very fast fermentation process (evidenced by low $B$ and high RM). This result was probably due to its high soluble sugars contents (A fraction). Interestingly, oat values were very high compared to in situ observations. As reported by Van Soest et al., (1992), maize proved to be the slowest because of its high starch content ( $B_{1}$ fraction), which degraded slowly. Hard and soft wheat showed very similar fermentation characteristics according to their chemical composition. Barley has fermentation kinetics between those of wheat and maize. Results related to these last three grains were similar to the results obtained in vitro using the IGPT (Mould et al., 2005). 


\begin{tabular}{|c|c|c|c|c|c|c|c|}
\hline & Barley & Maize & Oats & $\begin{array}{c}\text { Hard } \\
\text { wheat }\end{array}$ & $\begin{array}{c}\text { Soft } \\
\text { wheat }\end{array}$ & Faba bean & Pea \\
\hline $\begin{array}{c}\text { CP } \\
\text { (\% DM) }\end{array}$ & 11.0 & 8.79 & 12.2 & 14.4 & 13.5 & 29.8 & 23.9 \\
\hline A & 3.80 & 0.49 & 12.6 & 2.40 & 5.00 & 6.00 & 18.0 \\
\hline B1 & 66.4 & 75.4 & 45.6 & 67.6 & 65.7 & 43.6 & 40.8 \\
\hline B2 & 11.4 & 6.14 & 16.0 & 9.86 & 9.64 & 9.99 & 7.92 \\
\hline C & 3.60 & 2.57 & 6.77 & 2.64 & 2.16 & 6.41 & 4.18 \\
\hline
\end{tabular}

Table 3. Chemical composition and CNCPS fraction of the tested grains.

Legumes were characterised by high gas production alongside a rather slow fermentative process. However, interpretation of faba bean and pea data was complicated by their high protein content, whose degradation can interact with gas production (Schofield., 2000). Organic matter degradability for all tested grains was always higher than $95 \%$.

At $72 \mathrm{~h}$ the $\mathrm{pH}$ always remains good to guarantee microbial activity.

Oats reached the maximum rate before all the other grains (figure 2) and remained the highest until 12 incubation hours, subsequently decreasing below the soft wheat level. Until 6 hours of incubation barley was faster than the two wheat, later becoming slower until the end; up to this time the three sharp curves were practically overlapping, suggesting that the fermentation trend was similar for the three grains. Maize, faba bean and pea always showed the slowest fermentation rate with overlapping trends: fermentation slowly reaches its maximum rate and slowly decreases. The results of this investigation evidenced the validity of the IVGPT in describing the kinetics fermentation of the examined grains.

The range of rates obtained with the GPT (oats $>$ wheat $>$ barley>maize $>$ legumes) approximately reflects that reported by other authors cited by Sniffen et al. (1992): wheat>oats>barley>maize.

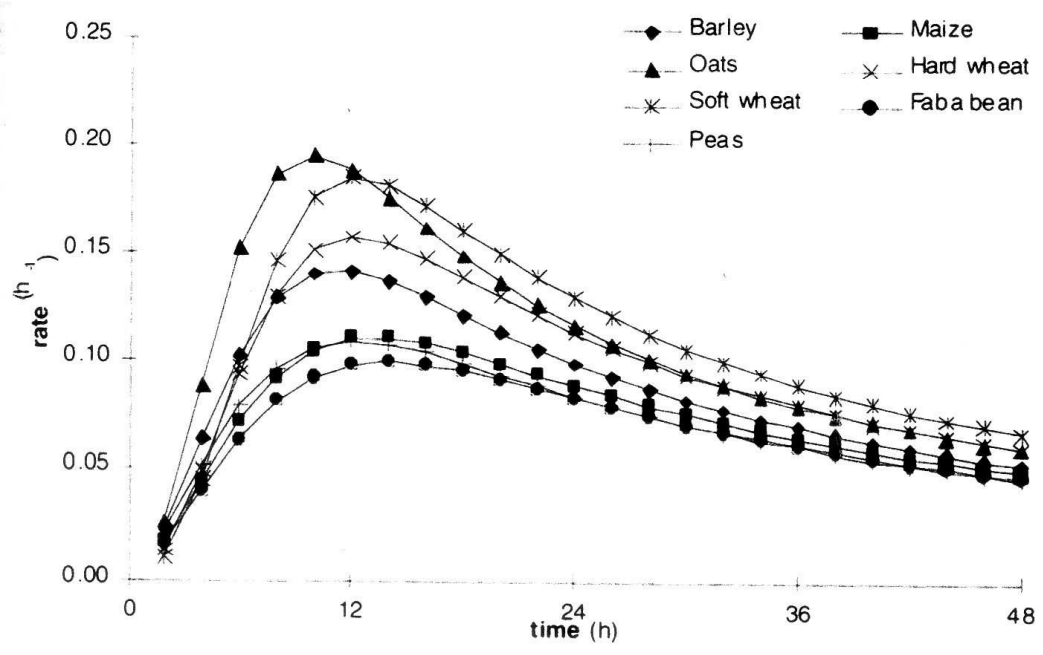

Fig. 2. Gas production fractional rate plots of different grains. 
In the second investigation Calabrò et al. (2001b) evaluated the effects of flaking and crushing on some cereal and legume grains, using the in vitro cumulative gas production technique (Theodorou et al., 1994).

The grains used in animal nutrition are commonly subjected to different technological treatments (i.e.: grounding, crushing, flaking, extrusion, cooking, micronization). Flaking is a hydrothermal-mechanical process which causes starch gelatinization and increases the enzymatic hydrolysis rate of the polysaccharide, which in turn favours the rumen microbial attack. Crushing differs from flaking in the shorter exposure to vapour. Also in this case, the obtained product presents a larger surface area compared to the primary grain, and a modified starch, which promotes faster fermentation kinetics.

Several investigations to evaluate the effect of flaking on organic matter degradability in the rumen, indicated the considerable influence of the primary grain (Arieli et al., 1995; Bittante et al., 1989); by contrast, little was known about the effects of crushing.

\begin{tabular}{|c|c|c|c|c|c|c|c|c|}
\hline & & $\mathrm{VC}_{\text {SOI }}$ & A & B & $\mathbf{R M}$ & $\mathrm{dOM}$ & $\mathbf{Y}$ & VFA \\
\hline & & $\mathrm{ml} / \mathrm{g}$ & $\mathrm{ml} / \mathrm{g}$ & $h$ & $h^{-1}$ & $\%$ & $\mathrm{ml} / \mathrm{g}$ & $\mathrm{mM} / \mathrm{g}$ \\
\hline \multirow{3}{*}{ Maize } & wholegrain & 340 & 362 & 14.9 & 0.078 & 92.9 & 363 & 99.1 \\
\hline & flaked grain & 338 & 347 & 13.2 & 0.096 & 96.6 & 343 & 83.3 \\
\hline & whole + flaked & $339 \mathrm{~A}$ & $355^{\mathrm{A}}$ & $14.1^{\mathrm{B}}$ & $0.087 \mathrm{~B}$ & 94.8 & $353^{A}$ & $91.2^{\mathrm{A}}$ \\
\hline \multirow{3}{*}{ Barley } & wholegrain & 304 & 323 & 10.2 & 0.125 & 90.6 & 341 & 92.4 \\
\hline & flaked grain & 346 & 369 & 11.7 & 0.104 & 97.9 & 359 & 94.8 \\
\hline & whole + flaked & $325^{\mathrm{B}}$ & $346^{\mathrm{A}}$ & $11.0^{\mathrm{C}}$ & $0.115^{\mathrm{A}}$ & 92.6 & $350 \mathrm{~A}$ & $93.6^{\mathrm{A}}$ \\
\hline \multirow{3}{*}{$\begin{array}{c}\text { Soybe } \\
\text { an }\end{array}$} & wholegrain & 204 & 236 & 15.5 & 0.051 & 96.7 & 209 & 71.6 \\
\hline & flaked grain & 225 & 280 & 19.8 & 0.039 & 86.8 & 257 & 76.0 \\
\hline & whole + flaked & $215^{C}$ & $258^{\mathrm{B}}$ & $17.6^{\mathrm{A}}$ & $0.045^{\mathrm{C}}$ & 91.8 & $233^{\mathrm{B}}$ & $73.8^{\mathrm{B}}$ \\
\hline \multicolumn{9}{|c|}{ Main effect } \\
\hline & grain & $* * *$ & $* * *$ & $* * *$ & $* * *$ & n.s. & $* * *$ & ** \\
\hline & treatment & $* * *$ & ** & ** & n.s. & n.s. & ** & n.s. \\
\hline \multicolumn{9}{|c|}{ Interaction } \\
\hline & grain. $x$ treat. & $* * *$ & $* * *$ & $* * *$ & $* * *$ & $* * *$ & $* * *$ & n.s. \\
\hline & Var.er. & 87.9 & 135 & 1.21 & 0.00009 & 10.5 & 206 & 103 \\
\hline
\end{tabular}

OMCV, cumulative gas production related to incubated $O M$ at $120 \mathrm{~h} ; A$, potential gas production; B, time at which A/2 is produced; Rmax, maximum fermentation rate; Y, yield related to the degraded OM; VFA, volatile fatty acids related to degraded $O M$.

$a, b, c: P<0.05 ; A, B: P<0.001 n s$, not significant; ${ }^{* * *}: p<0.001$.

Table 4. In vitro fermentation characteristics of whole and flaked grains.

In this experiment three whole and flaked grains (barley, maize, soybean) and four whole and crushed grains (barley, oats, maize, faba bean) were used as test substrates. 
Fermentation characteristics (Table 4 and 5) were affected by the grain type and treatment; in addition, the two factors interacted with each other.

\begin{tabular}{|c|c|c|c|c|c|c|c|c|}
\hline & & $\begin{array}{c}\text { OMC } \\
\text { V }\end{array}$ & $\mathbf{A}$ & B & $\operatorname{Rmax}$ & dOM & $\mathbf{Y}$ & VFA \\
\hline & & $\mathrm{ml} / \mathrm{g}$ & & $H$ & $h^{-1}$ & $\%$ & $\mathrm{ml} / \mathrm{g}$ & $m M / g$ \\
\hline \multirow{3}{*}{ Oats } & whole grain & 321 & 334 & 10.6 & 0.107 & 87.8 & 362 & 90.6 \\
\hline & crushed grain & 272 & 311 & 10.3 & 0.106 & 86.9 & 332 & 90.5 \\
\hline & whole +crushed & $296^{B}$ & $322^{\mathrm{B}}$ & $10.4^{\mathrm{C}}$ & $0.0106^{\mathrm{Aa}}$ & $87.3^{\mathrm{aCD}}$ & $347^{B}$ & $90.5^{\mathrm{AB}}$ \\
\hline \multirow{3}{*}{ Faba bean } & whole grain & 335 & 360 & 14.4 & 0.071 & 96.7 & 344 & 94.3 \\
\hline & crushed grain & 325 & 367 & 14.8 & 0.062 & 89.9 & 359 & 79.3 \\
\hline & whole +crushed & $330^{\mathrm{A}}$ & $364^{\mathrm{A}}$ & $14.6^{\mathrm{A}}$ & $0.066^{\mathrm{B}}$ & $93.3^{\mathrm{B}}$ & $352^{\mathrm{B}}$ & $86.8^{\mathrm{AbB}}$ \\
\hline \multirow{3}{*}{ Maize } & whole grain & 324 & 348 & 12.2 & 0.099 & 97.6 & 331 & 90.6 \\
\hline & crushed grain & 327 & 350 & 13.4 & 0.092 & 96.7 & 338 & 100 \\
\hline & whole +crushed & $326^{\mathrm{Ab}}$ & $349^{A}$ & $12.8^{\mathrm{B}}$ & $0.096 \mathrm{AbC}$ & $97.2^{\mathrm{A}}$ & $335^{\mathrm{B}}$ & $95.5^{\mathrm{aA}}$ \\
\hline \multirow{3}{*}{ Barley } & whole grain & 310 & 327 & 8.68 & 0.138 & 81.5 & 398 & 77.3 \\
\hline & crushed grain & 370 & 386 & 9.59 & 0.128 & 90.1 & 395 & 91.7 \\
\hline & whole +crushed & 340Аа & $357 \mathrm{~A}$ & 9.13D & $0.133 \mathrm{D}$ & $85.8^{\mathrm{bD}}$ & $397 \mathrm{~A}$ & $84.5^{\mathrm{B}}$ \\
\hline \multicolumn{9}{|c|}{ Main effect } \\
\hline & Grain & $* * *$ & $* * *$ & $* * *$ & $* * *$ & $* * *$ & $* \star \star$ & $* \star *$ \\
\hline & Treatment & n.s. & n.s. & * & n.s. & n.s. & n.s. & n.s. \\
\hline \multicolumn{9}{|c|}{ Interaction } \\
\hline & gran $x$ treat & $* * *$ & $* * *$ & n.s. & n.s. & $* * *$ & $* * *$ & n.s. \\
\hline & Var. er & 204 & 398 & 0.73 & $1 \cdot 10^{-1}$ & 1.85 & 437 & 48.19 \\
\hline
\end{tabular}

OMCV, cumulative gas production related to incubated $O M$ at $120 \mathrm{~h} ; \mathrm{A}$, potential gas production; B, time at which $A / 2$ is produced; Rmax, maximum fermentation rate; Y, yield related to the degraded OM; VFA, volatile fatty acids related to degraded OM. $a, b, c: P<0.05 ; A, B: P<0.001 n s$, not significant; $* * *: p<0.001$.

Table 5. In vitro fermentation characteristics of whole and crushed.

Flaking increased the potential gas production $(\mathrm{A})$ for soybean and barley $(\mathrm{P}<0.01)$, and slowed their fermentation kinetics (increased $t / 1 / 2$ and decreased RM values). By contrast, maize flakes showed lower gas production $(\mathrm{P}<0.05)$ and the fermentation process was faster $(\mathrm{P}<0.01)$, compared to whole grain.

Organic matter degradability decreased after the treatment for soybean $(\mathrm{P}<0.01)$, while it increased for barley $(\mathrm{P}<0.01)$ and, not significantly, for maize. The slower fermentative process for barley flakes (increased $t / 1 / 2$ and decreased $R M$ values) agrees with the results of other authors on treated cereals for both in vitro (Bittante et al., 1989) and in situ experiments (Arieli et al., 1995).

Comparing each grain with the respective flakes, OM degradability did not strictly follow the trend of potential gas production, confirming that not all the degraded OM is fermented. This result holds mainly for soybean flakes, which had a higher $\mathrm{A}(\mathrm{P}<0.01)$ and a lower $\mathrm{dOM}(\mathrm{P}<0.01)$ compared to the whole grain.

Such decreased OM degradability was probably due to the thermal treatment causing a decrease in the rapidly degradable fraction (Sarubbi, 1999).

Overall, the two cereals showed higher gas and VFA production, as well as a faster fermentative process. 
Crushing showed slighter effects compared to flaking, and also the results of the grain $x$ treatment interaction were less important.

The different technological condition of the two treatments (less drastic for crushing) may well have contributed to this trend. In particular, crushed barley presents, with respect to the whole grain, the same behaviour as the flakes (higher $\mathrm{A}$ and $\mathrm{dOM}, \mathrm{P}<0.001$; higher $t / 1 / 2$ and lower RM, not significant).

Interestingly, there was a decrease in faba bean degradability due to the treatment $(\mathrm{P}<0.01)$, which agrees with the results of a contemporaneous in situ trial (Sarubbi, 1999). Besides, faba bean also showed a lower VFA concentration, which was probably also caused by the considerable decrease in their protein degradability $(\mathrm{P}<0.001)$ as found in situ (Sarubbi, 1999). As usually observed in vivo in young bulls fed a cereal-rich diet, $\mathrm{pH}$ values were always quite low.

In the third study Calabrò et al. (2009) evaluated the fermentation characteristics of different cultivars of grain legumes using IVGPT.

Three grain legumes were tested: lupine (Lupinus spp.) (Lublanc, Luteur, Multitalia), faba bean (Vicia faba L.) (Chiaro di Torre Lama, Irena, Lady, ProtHABAT69, Scuro di Torre Lama, Sicania) and peas (Pisum sativum) (Alembo, Alliance, Attika, Corallo, Iceberg, Ideal, Spirale).

The fermentation characteristics are reported in table 6 .

The values of $\mathrm{pH}$ ranged between 6.35 and 6.72, indicating a normal pattern of fermentation, and were consistent to the crude protein content.

As regards faba bean, the cultivar "Scuro di Torre Lama" showed significantly $(\mathrm{P}<0.01)$ lower values of $\mathrm{dOM}$ and OMCV than the other 5 cultivars.

In the case of lupine the cultivar "Lublanc" had lower $(\mathrm{P}<0.01)$ OMCV than the other 2 cultivars and for peas the cultivar "Spirale" produced less gas and showed a faster kinetics than the other 6 cultivars.

As expected, the OM degradability resulted very high in any case. However, comparing the pools of the grain legumes, dOM was in each case lower than that of soybean meal. OMCV was significantly $(\mathrm{P}<0.01)$ higher for pea than faba bean $(330 \mathrm{vs} .316 \mathrm{ml} / \mathrm{g}, \mathrm{P}<0.05)$ and lupine (330 vs. $258 \mathrm{ml} / \mathrm{g}, \mathrm{P}<0.01)$. Gas production of peas was always higher than that of lupine, faba bean and also soybean meal according to the results of Buccioni et al. (2007) who studied the in vitro fermentation of soybean meal, faba bean and pea, and found in the latter the best balance between energy and nitrogen inputs.

The slower fermentation kinetics of faba bean may be due to the content in polyphenols while that of lupine may be caused by the very low starch content (INRA, 1988).

From the data obtained, the authors concluded that the tested grain legumes show only few differences compared to soybean meal (higher $\mathrm{dOM}$ and lower $\mathrm{OMCV}$ ), consequently they may be considered in replacing, totally or partially, soybean.

The reported results are of particular importance as well as highlight the differences in dietary and nutritional characteristics of soybean and legume grains, provide data on the effects of the treatments of these feedstuffs and the differences among the cultivars present on the European market.

With this information, the nutritionist may from time to time choose the most suitable protein source in order to satisfy animal requirements ensuring the simultaneous availability of nitrogen and energy for the bacteria present in the rumen with beneficial effects on livestock production and environmental impact. 


\begin{tabular}{|c|c|c|c|c|c|c|c|c|}
\hline Cultivar & $\mathrm{pH}$ & dOM & OMCV & Yield & $\mathbf{A}$ & B & tmax & Rmax \\
\hline & & $\%$ & $\mathrm{ml} / \mathrm{g}$ & $\mathrm{ml} / \mathrm{g}$ & $\mathrm{ml} / \mathrm{g}$ & $h$ & $h$ & $\mathrm{ml} / \mathrm{h}$ \\
\hline \multicolumn{9}{|c|}{ Faba bean } \\
\hline Irene & 6.46 & 92.9 & 370 & 397 & 328 & 22.9 & 12.42 & 9.14 \\
\hline Lady & 6.35 & 93.3 & 354 & 363 & 333 & 24.5 & 15.67 & 9.26 \\
\hline $\begin{array}{l}\text { Scuro di Torre } \\
\text { Lama }\end{array}$ & 6.49 & 87.8 & 308 & 351 & 269 & 22.0 & 15.39 & 8.84 \\
\hline $\begin{array}{l}\text { Chiaro di Torre } \\
\text { Lama }\end{array}$ & 6.41 & 91.8 & 348 & 379 & 310 & 23.1 & 13.20 & 8.69 \\
\hline ProtHABAT69 & 6.47 & 93.8 & 359 & 383 & 303 & 20.2 & 12.49 & 10.02 \\
\hline Sicania & 6.40 & 92.9 & 324 & 349 & 299 & 21.0 & 12.83 & 9.71 \\
\hline MSD & 0.135 & 3.19 & 60.1 & 49.3 & 60.1 & 3.90 & 3.65 & 1.89 \\
\hline \multicolumn{9}{|c|}{ Lupine } \\
\hline Lublanc & 6.63 & 93.4 & 256 & 279 & 283 & 26.1 & 10.25 & 6.73 \\
\hline Luteur & 6.69 & 92.4 & 275 & 298 & 309 & 25.6 & 5.58 & 7.83 \\
\hline Multitalia & 6.72 & 91.2 & 273 & 297 & 303 & 27.0 & 8.48 & 7.08 \\
\hline MSD & 0.219 & 5.40 & 26.6 & 91.5 & 13.9 & 45.8 & 15.6 & 4.74 \\
\hline \multicolumn{9}{|c|}{ Peas } \\
\hline Alembo & 6.57 & 99.0 & 406 & 410 & 361 & 20.6 & 12.52 & 11.73 \\
\hline Alliance & 6.49 & 99.3 & 397 & 396 & 358 & 20.1 & 11.99 & 11.72 \\
\hline Attika & 6.57 & 98.4 & 397 & 404 & 360 & 20.5 & 11.82 & 11.46 \\
\hline Corallo & 6.53 & 98.9 & 393 & 394 & 365 & 22.3 & 11.42 & 10.38 \\
\hline Iceberg & 6.55 & 98.8 & 381 & 385 & 347 & 21.0 & 12.45 & 10.86 \\
\hline Ideal & 6.58 & 97.0 & 371 & 383 & 336 & 20.7 & 13.24 & 11.06 \\
\hline Spirale & 6.58 & 98.8 & 344 & 343 & 310 & 17.1 & 10.66 & 12.14 \\
\hline MSD & 0.188 & 2.81 & 52.5 & 53.5 & 3.68 & 74.1 & 5.22 & 2.47 \\
\hline Faba bean ${ }^{1}$ & $6.52 \mathrm{Ab}$ & $90.9 \mathrm{~b}$ & $368 B$ & $405 \mathrm{~A}$ & $321 \mathrm{a}$ & $21.1 \mathrm{ab}$ & 12.4 & $10.0 \mathrm{Ab}$ \\
\hline Lupine $^{1}$ & $6.64 \mathrm{~B}$ & $91.8 \mathrm{ab}$ & $284 C$ & $309 B$ & $293 b$ & $24.4 a$ & 9.03 & $7.42 \mathrm{~B}$ \\
\hline Peas $^{1}$ & $6.60 \mathrm{a}$ & $95.1 \mathrm{a}$ & $394 \mathrm{~A}$ & $413 \mathrm{~A}$ & $336 a$ & $18.2 b$ & 11.4 & $12.6 \mathrm{Aa}$ \\
\hline Soybean meal $^{2}$ & 6.73 & 96.5 & 295 & 306 & 323 & 18.7 & 6.01 & 10.67 \\
\hline MSE & 0.001 & 2.31 & 56.2 & 30.5 & 101 & 4.40 & 2.99 & 0.56 \\
\hline
\end{tabular}

MSD: Minimum Significant Differences for P<0.01. MSE: Mean Square Error., In the column A,B,C: P<0.01; $a, b, c: P<0.05$. ${ }^{1}$ Data obtained from the grain legumes incubated in vitro as a pool. ${ }^{2}$ Data not statistically assessed.

Table 6. Fermentation characteristics of the different grain legume cultivars and soybean meal.

\section{Effect of different protein sources on animal performance}

Several researches have been carried out in order to compare the nutritional characteristics of soybean solvent extract and legume grains, as faba bean, peas and lupine, for ruminant feeding.

Di Francia et al. (2007) evaluated the effect of partial replacement of soybean cake with extruded peas in the diet of lactating buffalo cows on milk yield and quality over the first 100 days of lactation. Their results showed that peas could represent an attractive GMO free 
protein feed when approaching the problem of the choice of a protein source alternative to soybean in diet formulation for buffalo cows raised in organic farms.

On the other hand Morbidini et al (2005) investigating on the effect of two different fattening diets with different protein sources - soybean meal and flaked faba bean - on slaughtering performance and carcass quality in light Apennine and Italian Merino lambs, observed that the use of faba beans lightly depressed growth performance (Morbidini et al., 2004) and slaughtering weight, even if did not affect the carcass quality.

In order to make a contribution on this issue, our research group conducted a trial on the effect of protein source on growth performance and meat quality of Marchigiana young bulls (Cutrignelli et al $2008 \mathrm{a}, \mathrm{b}$ ).

The trial was carried out on a farm situated at $700 \mathrm{~m}$ a.s.l. in Campania Region (Southern Italy), where 12 weaned young bulls ( $129 \mathrm{~d}$ of age) were equally divided into two groups. Each animal was placed in individual box up to the slaughtering weight $(620 \mathrm{~kg})$.

The groups were fed diets with the same protein and energy concentrations and the same forage/concentrate ratios (F/C), but differing in protein source: faba bean (Vicia faba minor L.) vs soybean meal (Soja hispida).

All the animals were regularly weighed until the body weight (BW) of $620 \mathrm{~kg}$ fixed in advance as slaughter weight, was reached. All animals were slaughtered in an authorized slaughterhouse according to EU legislation (EU Regulation EC No 882/2004).

Live animals and carcasses were weighed and measured according to ASPA (1991). After 9 days of refrigeration at $4 \pm 1{ }^{\circ} \mathrm{C}$, dissection of the carcasses was carried out.

Samples of Longissimus thoracis (LT), Semitendinosus (ST), Iliopsoas plus Psoas minor (IP) muscles, perirenal (PF) and subcutaneous (SF) adipose tissues were collected and rapidly transported, upon refrigeration temperature, to the laboratories for the chemical analysis in order to evaluate the rheological (water holding capacity) and nutritional (chemical composition fatty acid profile, cholesterol and hydrossiproline contents) characteristics of meat.

The protein source did not affect any infra vitam parameters except the body weight (BW) at $180 \mathrm{~d}$ of age ( $173 \mathrm{vs.} 186 \mathrm{~kg}$, for group FB and SB, respectively; $\mathrm{P}<0.01$ ).

The difference was probably due to the higher non-protein nitrogen (NPN) concentration of the faba bean than the soybean meal (about 12 vs $1.3 \%$ of crude protein, respectively). Indeed, in the months immediately following the weaning it should be preferable to administer diets with higher rumen undegradable protein content because at this age the rumen is not yet perfectly functional and microbial protein synthesis is less efficient. Furthermore, for the same reason, the animals in this period are probably unable to neutralize possible anti-nutritional factors of faba beans.

As respects the influence of the replacement of soybean meal solvent extract with legumes seeds, the literature results are contrasting. Moss et al. (1997) found no significant effects on weight gain and feed intake when soybean meal was replaced on an iso-protein basis by lupin seeds in diets for growing bulls (BW from 182 to $243 \mathrm{~kg}$ ); similar results are reported by Kwak and Kim (2001) on Korean native bulls (BW from 247 to $427 \mathrm{~kg}$ ) utilising two different concentrations (15 and 30\%) of flaked lupin. Instead, according to our results, Murphy and McNiven (1994) found significantly higher weight gain in growing steers (BW from 235.2 to $343.7 \mathrm{~kg}$ ) fed soybean meal vs raw or roasted lupin although the differences were not significant in the finishing phase (final BW $503.4 \mathrm{~kg}$ ). 
No significant differences between the groups were found for carcass measurements. In each case the carcass measurements of this trial ranged into the interval indicated by Keane (2003) for European/North American breeds.

No differences were found in dressing out, organs and tare incidence on net weight.

Protein source influenced neither body and carcasses conformations nor dressing out with the exception of the incidence of long bones showed a significant difference (6.2 vs 6.7 for faba and soybean, respectively; $\mathrm{P}<0.05)$.

The first quality meat cuts were acceptable in both groups (58.1 and $57.8 \%$, for faba and soybean, respectively). Concerning the comparison between the two protein sources, only the incidence of long bones showed a significant difference (6.2 vs 6.7 for faba and soybean, respectively; $\mathrm{P}<0.05)$. It is important to underline that the sample cut measurements were contradictory and conflicted with the data obtained from total carcass dissection. The results of the sample cut dissection indicated a significant $(\mathrm{P}<0.05)$ difference between groups faba and soybean in meat incidence (69.4 vs 66.9 , for faba and soybean, respectively); while no differences were found between groups at carcass dissection. Moreover, sample cut of soybean group showed in the meantime the smallest meat incidence and the highest LT area ( 88.4 vs. 84 for soybean and faba group, respectively).

The animals fed faba bean showed significantly higher water losses, measured with the compression method (WHC 7.6 vs. $5.7 \%$ for faba and soybean group, respectively; $\mathrm{P}<0.01$ ).

Our grilling loss data ( 31.7 vs. $28.3 \%$ for faba and soybean group, respectively; $\mathrm{P}>0.01$ ) were higher than those reported by Sami et al. (2004) in Simmental young bulls but they were in agreement with those reported by Pen et al. (2005) cooking ST samples of Holstein steers in an oven, on the contrary our drip loss data resulted higher than that reported by these authors.

The chemical composition of LT was not statistically different between groups. Meat from both groups showed a very low fat content $(<3 \%)$ and higher protein concentrations than the Holstein steers (Pen et al., 2005), confirming the high quality of the Marchigiana meat.

Hydroxyproline (60.0 vs. $62.6 \mathrm{mg} 100 \mathrm{~g}^{-1}$ of meat, in group faba and soybean, respectively) contents were not influenced by protein sources. Regarding the differences registered for this parameter among the texted muscles (LT: Longissimus thoracis; ST: Semitendinosus; IP: Iliopsoas plus Psoas minor) the IP samples, which correspond to the tenderloin, showed in all the groups significantly $(\mathrm{P}<0.01)$ lower hydroxyproline concentrations than the other two muscles; also between the LT and ST muscles the differences were statistically significant $(\mathrm{P}<0.05)$ being lower for the former.

Cholesterol content (56.3 vs.55.1 mg $100 \mathrm{~g}^{-1}$ of meat, in group faba and soybean, respectively) was not influenced by protein sources according to the observations of Cutrignelli (2000) on Podolian young bulls and by Poli et al. (1996) on Chianina young bulls.

Considering the differences among the muscles, cholesterol values were significantly $(\mathrm{P}<0.05)$ lower for IP. Cifuni et al. (2004) found no differences in cholesterol contents among muscles, while Rusman et al. (2003) found significant differences. This contradiction is probably due to the different muscles analysed in each experiment. As theorised by Wheeler et al. (1987) the cholesterol content may be affected by the different physiological function of the muscles. In both groups, and especially for LT and ST muscles, the cholesterol contents

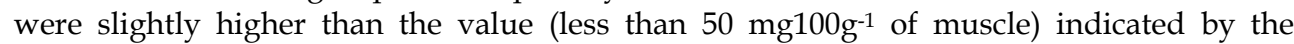
Protected Geographical Indication (PGI) of the "Vitellone Bianco dell' Appennino Centrale" (Council Regulation EEC No 2081/92; Floroni, 2002). Nevertheless, our results are very close 
to those reported for Italian meat breeds (Poli et al. 1996; Cifuni et al., 2004) and lower than those from other breeds (Migdal et al., 2004).

Regarding the fatty acids profile in both groups and in each analysed tissues (intramuscular, perirenal and subcutaneous adipose tissues) palmitic (C16:0), stearic (C18:0) and oleic (C18:1) acids were the most widely represented fatty acids. In particular, in intramuscular fat, the sum of oleic, stearic and palmitic acids represents over $50 \%$ of total fatty acids, according to the observations of Cifuni et al. (2004) and Migdal et al. (2004).

Comparing the data of groups faba and soybean, the only significant $(\mathrm{P}<0.01)$ difference was for stearic acid being higher for bulls fed faba bean than for those fed soybean meal solvent extract. However this result did not significantly affect the SFA concentration, or AI and TI indexes (table 7).

Protein source did not affected the fatty acids composition of the analysed adipose tissues. This is probably due to the very low concentration of phospholipids in subcutaneous and perirenal fat tissue.

Comparing the fatty acid composition of the three adipose tissues the following differences were noted:

- the erucic (C22:1), docosahexaenoic (DHA, C22:6, $\omega$-3) eicosapentaenoic (C 20:5, $\omega-3$ ) and docosapentaenoic (C 22:5, $\omega$-3) acids, were present only in intramuscular fat, due to the lower level of intramuscular fat compared to the two adipose tissues. Lower fat content is associated with fewer and smaller adipocytes containing fewer triglycerides, accompanied by a relative increase in the proportion of phospholipids in total lipids and an increased PUFA content (Scollan et al., 2006);

- $\quad$ the proportion of total SFA was minimal in LT and maximal in SF (mean values 46.56 vs 54.50 and $59.35 \%$ of total fatty acids; in LT, PF and SF, respectively, Figure 1); the single saturated fatty acids amounts also showed a similar trend. These data are partly in contrast with those of Kim et al. (2004) who in Hanwoo cattle found a higher SFA proportion in perirenal than in subcutaneous fat. Even if the differences in the fatty acids profile between internal and external fat deposits have not been fully elucidated, Eguinoa et al. (2003) suggested that the lipogenic enzyme activities per cell could be influenced by several factors such as adipocite size, nutrient supply, etc.;

- the proportion of total polyunsaturated fatty acids (PUFA) was higher in LT and lower in the perirenal adipose tissue (mean values 22.23 vs 11.36 vs $11.02 \%$ of total fatty acids, respectively in LT, SF and PF, Figure 1). This difference may be primarily ascribed to the lower concentration of $\omega-6$ PUFA and to the absence DHA in SF and PF adipose tissues;

- the atherogenic and thrombogenic indexes were considerably higher in SF and PF tissues than in LT. This is due to the high SFA concentration of SF and PF adipose tissues as well as to the high PUFA concentration of LT.

The LT fatty acid profile was similar to those reported by Raes et al. (2003) for Longissimus

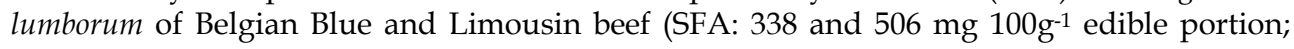

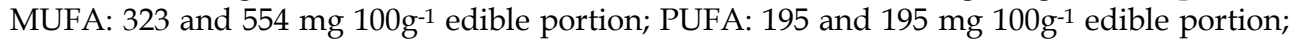
in Belgian Blue and Limousin bulls, respectively) and different from values found in Irish and Argentine beef. The latter showed significantly higher total intramuscular fatty acid content compared to the former, probably due to genetic selection.

This observation confirms that of Carnovale and Nicoli (2000) who concluded that Italian meat showed a favourable intramuscular fatty acid composition with high PUFA content. Muscle with a high percentage of unsaturated fatty acids (UFA) generally scored higher in 
taste panel evaluation (Westerling and Hedrick, 1979) and food with high UFA, especially PUFA, is good for human health (Rusman et al., 2003). The $\omega-6 / \omega-3$ ratio was higher than the value (less than 3) reported by Scollan et al. (2006) but lower than that registered by Warren et al. (2003) for steers fed corn silage and concentrates (8.9).

It has to be underlined that the fatty acid profile o the food arouse high interest in human medicine due to their influence on the functionality of the cardio-circulatory apparatus. A number of epidemiological researches put in evidence that diets with high content of saturated fatty acids (SFA) were associated with high levels of serum cholesterol (especially of low density lipoprotein, LDL) which appear important in atheroma. Successively, Ulbricht and Southgate (1991) reported that:

1. diets high in C18:0, stearic acid, do not raise serum cholesterol;

2. short-chain SFA (C 10 and below) likewise do not raise blood cholesterol, so the putative atherogenic SFA are C12:0 (lauric), C14:0 (myristic) and C16:0 (palmitic). Myristic acid is the most atherogenic, with about four times the cholestrol-raising potential of palmitic acid.

PUFA are considered protective factors: $\omega-6$ fatty acids show mainly anti-atherogenic activity while $\omega-3$ fatty acids have anti-thrombogenic activity. More recently, high prominence is attributed to the role developed by the MUFA, and particularly by the oleic acid that, reducing the oxidation of the cholesterol LDL, may slow the progression of atherosclerosis.

As was pointed out above, the $\mathrm{P} / \mathrm{S}$ (poliunsaturated/saturated) ratio is not suitable measure of the atherogenicity or thrombogenicity of a diet or foods. Currently they are expressed as follows:

$$
\text { Index of atherogenicity: C12:0 + }(4 \times \mathrm{C} 14: 0)+\mathrm{C} 16: 0 / \omega-3+\omega-6+\text { MUFA }
$$

Index of thrombogenicity: C14:0 + C16:0 +C18:0/ $(0,5 \times \mathrm{C} 18: 1)+(0,5$ other MUFA $)+0,5(\omega-6)+$

$$
3(\omega-3)+(\omega-3 / \omega-6)
$$

The AI of the meat in this trial was particularly interesting, rather lower than the data reported by Ulbricht and Southgate (1991) for raw minced beef and than those reported by Badiani et al. (2002) for cooked beef ( 0.72 and 0.77 , respectively); our data were similar to those of Poli et al. (1996) on Chianina young bulls (AI: 0.58).

\begin{tabular}{|c|c|c|c|}
\hline & FB & SB & Significance \\
\hline SFA & $365.1 \pm 39.1$ & $330.6 \pm 26.9$ & Ns \\
\hline MUFA & $244.3 \pm 39.5$ & $271.7 \pm 29.4$ & Ns \\
\hline PUFA & $186.6 \pm 20.5$ & $201.9 \pm 15.7$ & Ns \\
\hline$\omega-6$ & $174.2 \pm 19.9$ & $188.3 \pm 12.9$ & Ns \\
\hline$\omega-3$ & $12.39 \pm 1.5$ & $13.57 \pm 0.8$ & Ns \\
\hline AI & $0.54 \pm 0.04$ & $0.49 \pm 0.07$ & Ns \\
\hline TI & $1.46 \pm 0.12$ & $1.20 \pm 0.09$ & \\
\hline
\end{tabular}

FB: faba bean; SB: soybean meal solvent extract;AI: atherogenic index; TI thrombogenic index. ns: not significant.

Table 7. Fatty acid profile of Longissimus thoracis muscle (mg $100 \mathrm{~g}^{-1}$ of edible part). 
However, the index of thrombogenicity in this trial was higher than the findings of the above-cited authors (1.27 and 1.30 for Ulbricht and Southgate, 1991 and Poli et al., 1996, respectively); only the TI (1.77) reported by Badiani et al. (2002) was similar to our data.

These results show that the faba bean could be used as an alternative protein source to soybean meal solvent extract as it did not affect the growth rate (body weight, daily weight gain and biological efficiency of growth) or the feed conversion indexes during the whole experimental period, and offers decided agronomical, economical and healthy advantages.

Nevertheless, in the first period after weaning the faba bean reduced the growth rate, probably due to the higher concentrations of NPN and anti-nutritional factors. It might be useful in this period to use this protein source associated with other richer in rumen undegradable.

Our results contribute to show that both protein sources (soybean meal and faba bean) could be utilised in the diet for young Marchigiana bulls ensuring the high quality of the meat obtained by this breed.

Although the meat of group fed faba bean had significantly higher concentrations of stearic acid compared to the level found in soybean group, neither the atherogenic and thrombogenic indexes, nor the cholesterol content were influenced.

As regards the effect of protein source on organolepitc characteristics, our results on hydroxyproline content and water holding capacity were conflicting. While the meat of the group fed soybean meal solvent extract showed a potential low tenderness (higher level of hydroxiproline) the water holding capacity measured by compression was lower for the group receiving faba bean.

From our results it is also possible to formulate a favourable assessment of the nutritional characteristics of the of meat Marchigiana young bulls. Indeed, the cholesterol values were very close to those indicated by the PGI of the "Vitellone Bianco dell' Appennino Centrale" and lower than those found in other breeds. Moreover, the fatty acids profile of LT confirms that the meat of the Italian breed specialised in meat production has higher unsaturated fatty acids concentration and lower saturated fatty acids levels, which in turn ensures medium-low atherogenic and thrombogenic indexes.

\section{Conclusions}

The protein source largely used in ruminant nutrition (soybean, soybean meal solvent extract and grain legumes) are characterised by several differences in chemical composition, in particular as concerns crude protein, ether extract and carbohydrates concentrations. Also the technological treatments as flaking and crushing could affect these parameters. In addition, mainly concerning the grain legumes, the contents of different nutrients is affected by the cultivar.

In order to better estimate the nutritive value of protein source, the in vitro gas production technique seems to be the most useful methods, as it allow to study also the kinetics of degradation in the rumen. The knowledge of the latter phenomenon is particularly useful, since the nutritionist may choose to treat a particular protein source in order to synchronize the availability of nitrogen and energy for rumen bacteria.

From our in vitro data, faba bean, lupin and peas, even if from different cultivars, may be considered in replacing, totally or partially, soybean as only few differences were found among these feeds. 
In addition, our in vivo studies concerning the infra vitam and post mortem performances of young bulls fed either faba bean or soybean showed:

- $\quad$ no influence of protein source on growth rate (body weight, daily weight gain and biological efficiency of growth) and feed conversion indexes;

- $\quad$ no influence of protein source on the nutritional characteristics of meat. Indeed, even if the meat of group fed faba bean had significantly higher concentrations of stearic acid compared to the level found in soybean group, neither the atherogenic and thrombogenic indexes, nor the cholesterol content were influenced;

- conflicting results on hydroxyproline content and on water holding capacity. Indeed, while the meat of the group fed soybean showed a potential low tenderness (higher level of hydroxiproline), the water holding capacity measured by compression was lower for the group receiving faba bean.

From these results, it can be concluded that the use of grain legumes as a protein source in ruminant diets could be used as alternative to soybean meal. However, mainly in the intensive livestock system the soybean meal solvent extract represents the protein source par excellence for the high protein content (in particular undegradable fraction), the absence of anti-nutritional factors and the extremely favourable biological value of its proteins. Not insignificant, then is the economic assessment, soybean is, especially in the areas where the ruminants breeding has been particularly developed, the protein source with the quality/price ratio more favourable.

By contrast, it has to be underlined that biotech herbicide tolerant soybean continued to be the principal biotech crop in 2010, occupying 73.3 million hectares or $50 \%$ of global biotech area. Farm animals are currently fed soybean and soybean meal developed from genetic transformation. Europe is strongly dependent upon the American continent for its protein requirements amounting up to 90 to $95 \%$.

Thus, the possible risk connected to genetically modified organisms use in animal breeding has led to the reconsideration of animal production processes with special reference to the use of alternative protein sources (e.g. faba beans, dried peas, lupine seeds, chickpeas) able to replace soybean. These legumes have agronomic importance because they improve soil fertility and reduce nitrogenous dressing, with positive effects on environmental pollution. Moreover, they need a limited initial investment for their modest requirements of chemical and energetic inputs and their short culture cycle.

\section{References}

A.S.P.A. (1991). Metodologie relative alla macellazione degli animali di interesse zootecnico ed alla valutazione e dissezione della loro carcasse. Ed. ISMEA, Roma.

Akpinar, N., Akpinar, M.A. \& Türkoglu, S. (2001). Total lipid content and fatty acid composition of the seeds of some Vicia L. species. Food Chem., 74, pp. 449-453.

Arieli, A., Bruckental, I., Kedar. \& I., Sklan, D. (1995). In sacco disappearance Of starch nitrogen and fat in processed grains. Anim. Feed sci. Techn., 51, pp. 287-295.

Bach Knudsen, K.E. (1997). Carbohydrate and lignin contents of plant materials used in animal feeding. Anim. Feed Sci. Technol., 67, pp. 319-338.

Badgley, C., Moghtader, J., Quintero, E., Zakem, E., Chappell, M.J., Avilés-Vázquez, K., Samulon, A. \& Perfecto, I., (2007). Organic agriculture and the global food supply. Renew. Agric. Food Sys., 22, pp. 86-108. 
Badiani, A., Stipa, S., Bitossi, F., Gatta, P.P., Vignola, G. \& Chizzolini, R., (2002). Lipid composition, retention and oxidation in fresh and completely trimmed beef muscles as affected by common culinary practices. Meat Sci., 60, pp. 169-186.

Bézard, J., Blond, J.P., Bernard, A. \& Clouet, P., (1994). The metabolism and availability of essential fatty acids in animal and human tissues. Reprod. Nutr. Dev., 34, pp. 539568

Bittante, G., Chies, L., Fasone, V., Sinatra, M.C. \& Gallo, L. (1989). Degradabilità e digeribilita in vitro della sostanza organica di cereali fioccati e/o macinati. Zoot. Nutr. Anim., 15, pp. 613-626.

Brand, T.S., Brandt, D.A. \& Cruywagen, C.W. (2004). Chemical composition, true metabolisable energy content and amino acid availability of grain legumes for poultry. South African Journal of Animal Science, 34, pp. 116-122.

Boccioni, A., Minieri, S., Petacchi, F. \& Antongiovanni, M. (2007). Il favino (Vicia faba minor) e il pisello proteico (Pisum sativum) in sostituzione della farina di estrazione di soia nell'alimentazione zootecnica. Valutazione comparativa delle caratteristiche nutrizionali con metodi di laboratorio. Arsia, Toscana.

Bulson, H.A.J., Snaydon, R.W. \& Stopes, C.E., (1997). Effects of plant density on intercropped wheat and field beans in an organic farming system. J. Agric. Sci., 128, pp. 59-71.

Cabrera, C., Lloris, F., Giménez, R., Olalla, M. \& López, M.C. (2003). Mineral content in legumes and nuts: contribution to the Spanish dietary intake. The Science of total environment, 308, pp. 1-14.

Calabrò et al. (2010) www.progettobufale.it/pubblicazionenew.html

Calabrò, S., Marchiello, M. \& Piccolo, V. (2001a). In vitro fermentation of some cereals and legumes grains. Proc. XIII Congr. Naz. ASPA, Firenze (Italy), pp. 153-155.

Calabró, S., Piccolo, V., Bovera, F. \& Sarubbi, F. (2001b). In vitro fermentation kinetics of crushed and flaked grains. Proc. VI World Buffalo Congr., Maracaibo (Venezuela), pp. 478-484.

Calabrò, S., Tudisco, R., Balestrieri, A., Piccolo, G., Infascelli, F. \& Cutrignelli, M.I. (2009). Fermentation characteristics of different grain cultivars with the in vitro gas production technique. Ita, J. of Anim. Sci., 8, pp. 280-282.

Canibe, N., Bach Knudsen, K.E., (2002). Degradation and physicochemical changes of barley and pea fibre along the gastrointestinal tract of pigs. J. Sci. Food Agric., 82, pp. 27-39.

Carnovale, E. \& Nicoli, S., (2000). Changes in fatty acid composition in beef in Italy. J. Food Compos. Anal., 13, pp. 505-510.

Chalk, P.M., Smith, C.J., Hamilton, S.D. \& Hopmans, P., (1993). Characterization of the N benefit of a grain legume (Lupinus angustifolius L.) to a cereal (Hordeumvulgare L.) by an in situ $15 \mathrm{~N}$ isotope dilution technique. Biol. Fertil. Soils, 15, pp. 39-44.

Chaubility, U.B., Gupta, R., Bird, S.H. \& Mudgal, V.D., (1991). In sacco dry matter disappearance of different protein cakes in the rumen of male buffalo and their solubility in water. Proceedings of the 3rd World Buffalo Congress, Paestum (Italy), p. 165, Abstract.

Chumpawadee, S., Chantiratikul, A. \& Chantiratikul, P. (2007). Chemical composition and nutritional evaluation of protein feeds for ruminants using an in vitro gas production technique. Journal of Agricultural Technology pp. 191-202

Cifuni, G.F., Napolitano F., Riviezzi, A.M., Braghieri, A. \& Girolami, A., (2004). Fatty acid profile, cholesterol content and tenderness of meat from Podolian young bulls. Meat Sci., 67, pp. 289-297. 
Colombini, S.(2004). Resa proteica di alcune varietà di pisello, fava e lupino nell'Italia settentrionale. Informatore agrario, 60, pp. 73-75

Cone, J.W., van Gelder, A.H., Visscher, G.J.W. \& Oudshoorn, L. (1996). Influence of rumen fluid and substrate concentration on fermentation kinetics measured with a fully automated time related gas production apparatus. Animal Feed Science Technology, 61, pp. 113-128.

Council Regulation (EC) No 834/2007 on organic production and labelling of organic products and repealing Regulation (EEC) No 2092/91 L 189/1- L 189/23.

Council Regulation (EEC) No 2092/91 of 24 June 1991 on organic production of agricultural products and indications referring thereto on agricultural products and foodstuffs L 198 , 22/07/1991 P. $0001-0015$

Cutrignelli, M.I., (2000). Caratteristiche del taglio campione di mezzene di vitelloni Podolici sottoposti a differenti sistemi di allevamento. Proc. Nat. Congr: Parliamo di... on Breeding in the third Millennium, Fossano (CN), Italy, pp. 127-134

Cutrignelli, M.I., Piccolo, G., Bovera, F., Calabrò, S., D’Urso, S., Tudisco, R. \& Infascelli, F. (2008a) Effects of two protein sources and energy level of diet on the performance of young Marchigiana bulls. 1. Infra vitam performance and carcass quality. Ital.J.Anim.Sci., 7, pp. 259-270

Cutrignelli, M.I., Calabrò, S., Bovera, F., Tudisco, R., D’Urso, S., Marchiello, M., Piccolo, V. \& Infascelli, F. (2008b) Effects of two protein sources and energy level of diet on the performance of young Marchigiana bulls. 2. Meat qualità. Ital.J.Anim.Sci., 7, pp. 271-285.

Degussa, (2006). The amino acid composition of feedstuffs. 5th rev. ed., Degussa AG, Feed Additives, Hanau, Germany.

Di Francia, A., De Rosa, G., Masucci, F., Romano, R., Borriello, I. \& Grassi, C. (2007). Effect of Pisum sativum as protein supplement on buffalo milk production. Ital.J.Anim.Sci., 6, pp. $472-475$

Díaz -Ambrona, C.H. \& Mínguez, M.I. (2001). Cereal-legume rotations in a Mediterranean environment: biomass and yield production. Field Crops Research, 70, pp. 139- 51

DLG, (1999). Kleiner Helfer für die Berechnung von Futterrationen. Wiederkäuer und Schweine. DLG-Verlag, 10. Auflage, Frankfurt am Main, Germany.

Erbas, M., Certel, M. \& Uslu, M.K., (2005). Some chemical properties of white lupin seeds (Lupinus albus L.). Food Chem., 89, pp. 341-345.

European Commission directive, 999/2001. Regulation (EC) No. 999/2001 of the European Parliament and of the Council of 22 May 2001 laying down rules for the prevention, control and eradication of certain transmissible spongiform encephalopathies. Official Journal of the European Communities L 147/1-L 147/40.

European Commission, 1992. Council Regulation of 14 July 1992 concerning the protection of geographical indications and designations of origin for agricultural products and foodstuffs, 92/2081/EC. Official Journal, L 208, 24/07/1992, pp. 1-8.

European Commission, (2004). European Parliament and Council Regulation of the of 29 April 2004 concerning the official controls performed to ensure the verification of compliance with feed and food law, animal health and animal welfare rules, 882/2004/EC. Official Journal, L 165, 30/04/04, pp 1-141.

Evans, J., McNeil', A.M., Unkovich, M.J., Fettell, N.A. \& Heenan, D.P., (2001). Net nitrogen balances for cool-season grain legume crops and contributions to wheat nitrogen uptake: a review. Aust. J. Exp. Agric., 41, pp. 347-359.

Floroni, A. (2002). I.G.P. “Vitellone Bianco dell'Appennino Centrale”. L'Allevatore, 58, pp. 1213. 
Froud-Williams, R.J., (1988). Changes in weed flora with different tillage and agronomic management systems. In: Altieri, M.A. \& Liebman, M. (Eds.), Weed Management in Agroecosystems: Ecological Approaches. CRC, Boca Raton, Florida, pp. 213-236.

Gatel, F., (1994). Protein quality of legume seeds for non-ruminant animals: a literature review. Anim. Feed Sci. Technol., 45, pp. 317-348.

Getachew, G., Robinson, P.H., DePeters, E.J. \& Taylor, S.J. (2004). Relationships between chemical composition, dry matter degradation and in vitro gas production of several ruminant feeds. Animal Feed Science Technology, 111, pp. 57-71.

Gill, C., (1997). World feed panorama. High cost of feedstuffs: global impact, response. Feed International, 18, pp. 6-16.

Green, C.J. \& Blackmer, A.M., (1995). Residue decomposition effects on nitrogen availability to corn following corn or soybean. Soil Sci. Soc. Am. J., 59, pp. 1065-1070.

Groot, J.C.J., Cone, J.W., Williams, B.A. \& Debersaques, F.M.A., (1996). Multiphasic analysis of gas production kinetics for in vitro fermentation of ruminant feedstuff. Anim. Feed Sci. Tech., 64, pp. 77-89.

Herrero, M., I. Murray, R.H. Fawcett \& Dent, J.B. (1996). Prediction of in vitro gas production and chemical composition of kikuyu grass by near-infrared reflectance spectroscopy. Animal Feed Science Technology, 60, pp. 51-67.

Herridge, D.F., Macellos, H., Felton, W.L., Turner, G.L. \& Peoples, M.B., (1995). Chickpea increases soil-N fertility in cereal systems through nitrate sparing and $\mathrm{N}_{2}$ fixation. Soil Biol. Biochem., 27, pp. 545-551.

Huisman, J. \& Tolman, G.H., (2001). Antinutritional factors in the plant proteins of diets for non-ruminants. In: Garnsworthy, P.C. \& Wiseman, J. (Eds.), Recent Developments in Pig Nutrition, vol. 3. Nottingham University Press, Nottingham, pp. 261-322.

Infascelli, F., Di Lella, T. \& Piccolo, V., (1995). Dry matter, organic matter and crude protein degradability of high protein feeds in buffaloes and sheep. Zoot. Nutr. Anim., 21, pp. 89-94.

INRA (1988). Alimentation des bovins, ovins \& caprins. Paris.

Jezierny, D., Mosenthin, R. \& Bauer, E. (2010). The use of grain legumes as a protein source in pig nutrition: A review. Animal Feed Science and Technology, 157, pp. 111-128.

Jezierny, D., (2009). In vivo and in vitro studies with growing pigs on standardised ileal amino acid digestibilities in grain legumes. Ph.D. Thesis. University of Hohenheim, Stuttgart, Cuvillier Verlag Göttingen, Germany.

Jezierny, D., Mosenthin, R., Eklund, M. \& Rademacher, M., (2007). Determination of standardized ileal digestibilities of crude protein and amino acids in legume seeds for growing pigs. Proceedings of the 16th International Science Symposium on Nutrition of Domestic Animals, Radenci, pp. 198-203.

Keane, M.G., (2003). Beef production from Holstein-Friesian bulls and steers of New Zeland and European/American descent, and Belgian Blue $x$ Holstein-Fresians slaughtered at two weights. Livest. Prod. Sci., 84, pp. 207-218.

Kim, C.M., Kim, J.H., Chung, T.Y. \& Park, K.K., (2004). Effect of flaxseed diets an fattening response of Hanwoo cattle: 2 fatty acid composition of serum and adipose tissues. Asian-Aust. J. Anim. Sci., 9, pp. 1246-1254.

Lallès, J.P. \& Jansman, A.J.M., (1998). Recent progress in the understanding of the mode of action and effects of antinutritional factors from legume seeds in non-ruminant farm animals. In: Jansman, A.J.M., Hill, G.D., Liebman, M. \& Dyck, E.,. Crop rotation and intercropping strategies for weed management. Ecol. Appl. 3, pp. 92122. 
Liebman, M. \& Janke, R., (1990). Sustainable weed management practices. In: Francis, C.A., Flora, C.B. \& King, L.D. (Eds.), Sustainable Agriculture in Temperate Zones. John Wiley\&Sons, New York, pp. 111-143.

López-Bellido, F.J., López-Bellido, L. \& López-Bellido, R.J., (2005). Competition, growth and yield of faba bean (Vicia faba L.). Eur. J. Agron., 23, pp. 359-378.

Medsen, J., T. Hvelplund \& Weisbjerg, M.R. (1997). Appropriate method for the evaluation of tropical feeds for ruminants. Animal Feed Science Technology, 69, pp. 53-66.

Morbidini, L., Rossetti, E., Cozza, F. \& Pauselli, M. (2005). Different protein source (soybean or faba bean) in postweaning diets for Apennine and Sopravissana (Italian Merino) light lamb: slaughtering performances. Ital.J.Anim.Sci., 4, pp. 360-362.

Morbidini, L., Pauselli, M., Rossetti, E. \& Cozza, F., (2004). Diete post-svezzamento con differente fonte proteica (favino o soja) per la produzione di agnelli leggeri di razza Appenninica e Sopravissana: rilievi in vivo. Proc. Congr. "Parliamo di ... nuove normative in campo zootecnico", Cuneo, Italy, pp. 113-122.

Moss, A.R., Givens, D.I., Grundy, H.F. \& Wheeler, K.P.A., (1997). The nutritive value for ruminants of lupin seeds from determinate plants and their replacement of soybean meal in diets for young growing cattle. Anim. Feed Sci. Tech., 68, pp. 11-23.

Mould, F.L., Kliem, K.E. Morgan, R. \& Mauricio, R.M, (2005). In vitro microbial inoculum: A review of its function and properties Anim. Feed Sci. Technol., 123, pp. 31-50

Murphy, S.R. \& McNiven, M.A., (1994). Raw or roasted lupin supplementation of grass silage diets for beef steers Anim. Feed Sci. Tech., 46, pp. 23-35.

NRC (2001). Nutrient Requirements of Dairy Cattle: Seventh Revised Edition, 2001. National Academy Press, Washington, D.C.

NRC, (1998). Nutrient requirements of swine. 10th ed., National Academy Press, Washington, D.C.

Pen, B., Oyabu, T., Hidaka, S. \& Hidari, H., (2005). Effect of potato by-products based silage on growth performance, carcass characteristics and fatty acid composition of carcass fats in Holstein steers. Asian-Aust. J. Anim. Sci., 4, pp. 490-496.

Poli, B.M, Giorgetti, A., Bozzi, R., Funghi, R., Balò, F.\& Lucifero, M., (1996). Quantity and quality of lipid fractions for human nutrition in Chianina muscles as influenced by age and nutritive level. In: G. Enne and G.F. Greppi (eds.) Food \& Health: role of animal products, Proc. 31 st Int. Symp. of Società Italiana per il Progresso della Zootecnia held in Milano, Italy, Elsevier publ., Paris, France, pp. 199-204.

Raes, K., Balcaen, A, Dirinck, P., De Winne, A., Claeys, E., Demeyer, D. \& De Smet, S., (2003). Meat quality, fatty acid composition and flavour analysis in Belgian retail beef. Meat Sci., 65, pp. 1237-1246.

Rubio, L.A. \& Brenes, A., (1995). Utilization de leguminosas-grano en nutricion animal: problemas y perspectives. Proc. XI Curso de Especializacion FEDNA, Barcelona, Spain. www.cirval.asso.fr.

Rusman, S. \& Setiyono, A.S., (2003). Characteristics of Biceps femoris and Longissimus thoracis muscles of five cattle breeds grown in a feedlot system. J. Anim. Sci., 74, pp. 59-65.

Salgado, P., Freire, J.P.B., Mourato, M., Cabral, F., Toullec, R. \& Lallès, J.P., (2002a). Comparative effects of different legume protein sources in weaned piglets: nutrient digestibility, intestinal morphology and digestive enzymes. Livest. Prod. Sci., 74, pp. 191-202.

Salgado, P., Martins, J.M., Carvalho, F., Abreu, M., Freire, J.P.B., Toullec, R., Lallès, J.P. \& Bento, O., (2002b). Component digestibility of lupin (Lupinus angustifolius) and 
pea (Pisum sativum) seeds and effects on the small intestine and body organs in anastomosed and intact growing pigs. Anim. Feed Sci. Technol., 98, pp. 187-201

Sami, A.S., Augustini, C. \& Schwarz, F.J., (2004). Effect of feeding intensity and time on feed on performance, carcass characteristics and meat quality of Simmental bulls. Meat Sci., 67, pp. 195-201.

Sankara Rao, D.S. \&, Deosthale \& Y.G. (2006). Mineral Composition of Four Indian Food Legumes. Journal of Food Science, 46, pp. 1962-1963

Sarubbi, F. (1999). Studi sull'impiego di proteasi tioliche per la previsione della degradabilita ruminale delle proteine e sule modificazioni dell' attivita ruminale indotte nei bufali da razioni arricchite con Aspergillus oryzae. PhD Thesis, Univ. Napoli, 1-23. 1999.

Schofield, P. (2000). Gas production methods. In "Farm Animal Metabolism and Nutriion", J.P.F. D'Mello, ed. CAB International, Wallingford, Oxon, U.K, pp. 209-232.

Scollan, N., Hocquette, JF., Neuerbetg, K., Dannenberger, D, Richardson, I. \& Moloney, A., (2006). Innovations in beef production system that enhance the nutritional and health value of beef lipids and their relationship with meat quality. Meat Sci., 74, pp. 179-33.

Singh, R.J., Chung, G.H. \& Nelson, R.L., (2007). Landmark research in legumes. Genome, 50, pp. 525-537.

Sniffen, C. J., J. D. O'Connor, P. J. Van Soest, D. G. Fox \& J. B. Russell. (1992). A net carbohydrate and protein system for evaluating cattle diets: 11 . Carbohydrate and protein availability. J. Anim. Sci., 70, pp. 3562.

Sprent, J.I. \& Thomas, R.J., (1984). Nitrogen nutrition of seedling grain legumes: some taxonomic, morphological and physiological constraints. Plant Cell Environ., 7, pp. 637-645.

Theander, O., Westerlund, E., Åman, P. \& Graham, H., (1989). Plant cell walls and monogastric diets. Anim. Feed Sci. Technol., 23, pp. 205-225

Theodorou, M.K. (1994.) A new laboratory procedure for determining the fermentation Kinetics of ruminants feeds. Ciencia e Investigcion Agraria, 20, pp. 332-334

Trostle, R., (2008). Global agricultural supply and demand: Factors contributing to the recent increase in food commodity prices. A Report from the Economic Research Service. United States Department of Agriculture Economic Research Service, Washington, DC

Ulbricht, T.L.V. \& Southgate, D.A.T., (1991). Coronary heart disease: seven dietary factors. Lancet, 338, pp. 985-992.

Warren, HE., Enser, M., Richardson, I., Wood, JD.\& Scollan, N.D., (2003). Effect of breed and diet on total lipid and selected shelf-life parameters in beef muscle. Proc Nat. Congr. BSAS, York, UK. pp. 43.

Westerling, D.B. \& Hedrick, H.B., (1979). Fatty acid composition of bovine lipids as influenced by diet, sex and anatomical location and relationship to sensory characteristics. J. Anim. Sci., 48, pp. 1343-1348.

Wheeler, T.L., Davis, G.W., Stoeker, B.J.\& Hatmon, C.J., (1987). Cholesterol concentration of Longissimus muscle, subcutaneous fat and serum of two beef cattle breed type. $J$. Anim. Sci., 65, pp.1531-1537.

Wood, J.D., Richardson, R.I., Nute, G.R., Fisher, A.V., Campo, M.M., Kasapidou, E., Sheard, P.R. \& Enser, M., (2003). Effects of fatty acids on meat quality: a review. Meat Sci., 66, pp. 21-32.

Zahran, H.H., (1999). Rhizobium-legume symbiosis and nitrogen fixation under severe conditions and in an arid climate. Microbiol. Mol. Biol. Rev., 63, pp. 968-989. 


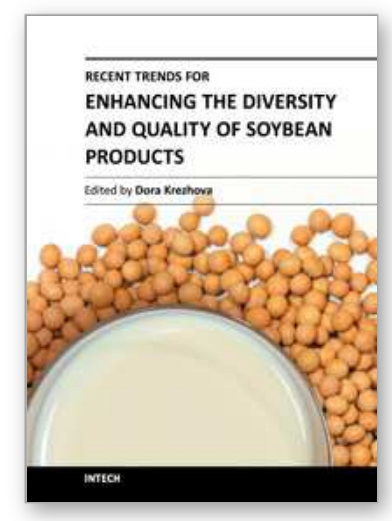

\author{
Recent Trends for Enhancing the Diversity and Quality of Soybean \\ Products \\ Edited by Prof. Dora Krezhova
}

ISBN 978-953-307-533-4

Hard cover, 536 pages

Publisher InTech

Published online 28, October, 2011

Published in print edition October, 2011

This book presents new aspects and technologies for the applicability of soybean and soybean products in industry (human food, livestock feed, oil and biodiesel production, textile, medicine) as well as for future uses of some soybean sub-products. The contributions are organized in two sections considering soybean in aspects of food, nutrition and health and modern processing technologies. Each of the sections covers a wide range of topics. The authors are from many countries all over the world and this clearly shows that the soybean research and applications are of global significance.

\title{
How to reference
}

In order to correctly reference this scholarly work, feel free to copy and paste the following:

Monica I. Cutrignelli, Serena Calabrò, Raffaella Tudisco, Federico Infascelli and Vincenzo Piccolo (2011). Protein Sources in Ruminant Nutrition, Recent Trends for Enhancing the Diversity and Quality of Soybean Products, Prof. Dora Krezhova (Ed.), ISBN: 978-953-307-533-4, InTech, Available from: http://www.intechopen.com/books/recent-trends-for-enhancing-the-diversity-and-quality-of-soybeanproducts/protein-sources-in-ruminant-nutrition

\section{INTECH}

open science | open minds

\section{InTech Europe}

University Campus STeP Ri Slavka Krautzeka 83/A 51000 Rijeka, Croatia Phone: +385 (51) 770447

Fax: +385 (51) 686166 www.intechopen.com

\section{InTech China}

Unit 405, Office Block, Hotel Equatorial Shanghai No.65, Yan An Road (West), Shanghai, 200040, China 中国上海市延安西路65号上海国际贵都大饭店办公楼405单元 Phone: +86-21-62489820

Fax: $+86-21-62489821$ 
(C) 2011 The Author(s). Licensee IntechOpen. This is an open access article distributed under the terms of the Creative Commons Attribution 3.0 License, which permits unrestricted use, distribution, and reproduction in any medium, provided the original work is properly cited. 